\title{
Application Of The Principles Of Insurance Law In Fire Insurance Agreements On Credit Guarantees Attached Object Security Rights
}

\author{
Rois Harliyanto ${ }^{1}$ and Sukarmi ${ }^{2}$
}

Abstract. The purpose of this study were 1) to know application of the principles of insurance law in fire insurance agreements on credit guarantees attached object security rights, 2) To know the weaknesses in the application of the principles of insurance law in fire insurance agreements on credit guarantees attached object security rights.

Approximation methodused is a normative juridical research that refers to the theories, doctrines, norms, principles, rules relating to matters pertaining to insurance law. The nature of this research was analytic descriptive depict or describe the facts with the implementation of analytical and systematic.

Based on this study concluded that 1) Application of the principles of insurance law in fire insurance agreements on credit guarantees attached object security rights are concerned principle consensual taken from one of the terms of agreement, namely the agreement of both parties. People can not be forced to give agreement. Agreed given by force is a contradiction interminis. Coercion indicates the absence of agreement that may be performed by other parties. The deal gives the option to the parties, to agree or disagree bound by a treaty with legal consequences. 2) A weakness in the application of the principles of insurance law in fire insurance agreements on credit guarantees attached object encumbrance is Risk Coverage and Exclusions goods insured.

Keywords: Principles of Law; Insurance, Agreements; Fire; Collateral Loans; Mortgage.

\section{Introduction}

Agreements are generally arranged in book III of the Civil Code, the definition of the agreement itself, under Article 1313 of the Civil Code which states that the agreement is an act by which one or more persons bind himself to one or more other people. Thus, the agreement is a legal relationship between two or more parties based on an agreement to give rise to legal consequences. Law relationship is a relationship which consequently governed by the law it is worth noting because in daily life there are many relationships that consequently regulated by law.

In a treaty agreement is an essential element or the first to the validity of an agreement pursuant to Article 1320 of the Civil Code. If one of the properties contained in the Article are not met or there is coercion, mistake, or deception of the agreement can be canceled. This happens defect in an agreement that has been agreed in advance by both parties. If the agreement is violated party who feels aggrieved can demand that the other party subject to sanctions or punishment. Because insurance is included in the agreement then applies sanctions or penalties for noncompliance with under the provisions of Article 1 of the Code of Trade Law, basically provisions on the engagement and the agreement contained in the book III of the Civil Code can also be applied treated insurance agreement.

\footnotetext{
${ }^{1}$ Kepala PT Asuransi Wahana Tata (Astata) Cabang Solo, E-mail: rois.harliyanto@yahoo.co.id

2 Faculty of Law Universitas Islam Sultan Agung
} 
The insured person and the insurer has the rights and obligations of each, the insured person must make premium payments under the agreement or collective agreement. Likewise, the insurer must provide compensation to the insured when there is a risk in the future.

The risks that loss, then through insurance agencies can be routed to overcome that with the provision of compensation by the insurance agency when the risk of it actually happening. Insurance undertakings as one of the financial institutions, becomes important because of the business activity is expected to further increase further the deployment of public funds for development financing.

Insurance companies hold agreements with insurers and later at some point the insurance company to perform its obligations under the agreement. In this case the company serves as the recipient institutions and other parties risk takers. Payment amount of money called a premium constitutes acceptance and takeover risks by insurance companies. A collection of funds to be very large relative of the payment of the premium received by the company can be used for the operations of the company. ${ }^{3}$

Based on this concept of insurance is important role in socio-economic life of human beings, so that if the concept of insurance is rated as the concept of "popping". Starting from the role essentially as a means to reproduce a sense of security for the insured, to the long-term role as a means of supporting the country's economy. In essence, the concept of insurance is a classic concept that has long been used in the history of the social order. This concept coincided with the emergence of the concept of mutual help between individuals.

Insurance is one alternative that a solution to these uncertainties. An insurance company stand provides various services such as protection of life, damage to property owned by clients or potential clients of insurance. The property damage or may be caused by natural disasters, fire, collision for motor vehicles, and so forth. Furthermore, there are also insurance services in terms of preparation for the future in the form of insurance plus children's education savings services, the retirement and old age.

Insurance does provide a lot of benefits to the community, but insurance become a thing reluctant to follow because the ancient problems that often face, the problem is not about the settlement of claims that is considered difficult and complicated by the heirs of the insured or beneficiaries. Fulfillment of insurance claims is an obligation that must be carried by the person, it is as a consequence of the implementation of the pact as the Code Article 1234 Civil Code, "each engagement is to give something, to do something, or to do nothing". In the context of the insurance agreement, the subject is an agreement to do something. Insurer for the party that promises to provide reimbursement for any damage or loss or liability incurred legal or insurance benefits. ${ }^{4}$

According to the provisions of Article 225 KUHD insurance agreement must be in writing in the form of a deed called a policy that includes agreements, special conditions and specific promises on which the fulfillment of the rights and obligations of the parties (insurer and insured) in achieving the objectives of insurance. Thus, the policy is written evidence about the occurrence of the insurance agreement between the insured and the insurer. The role of insurance companies as one of the nonbanking financial institution that has the function to transfer risks and provide

\footnotetext{
${ }^{3}$ Annonimous. Perjanjian-Asuransi . http://jurnal.kesimpulan.com/html. Retrieved March 25. 2019

${ }^{4}$ Junaidi Ganie. 2013. Hukum Asuransi Indonesia. Sinar Grafika. Jakarta. p. 67.
} 
compensation in the event of an event does not necessarily (evenemen), it becomes very important and necessary to address the risks that may occur during the execution of credit. So to address the risk, the bank can work with several insurance companies to secure collateral (guarantee) of the credit agreement. ${ }^{5}$ Ordinary collateral attached to the guarantee of mortgage. Collateral or arise because of the obligations agreed upon in the contract agreement between the customer and bank financing.

Based on the background of the problems mentioned above, then the problem can be formulated as follows: How the application of the principles of insurance law in fire insurance agreements on credit guarantees attached object of mortgage? What are the weaknesses in the application of the principles of insurance law in fire insurance agreements on credit guarantees attached object of mortgage?

\section{Research methods}

Approximation method used is a normative juridical research that refers to the theories, doctrines, norms, principles, rules relating to matters pertaining to insurance law and norms apply in the application of legal principles of fire insurance in the insurance agreement. The nature of this research was analytic descriptive depict or describe the facts with the implementation of analytical and systematic. ${ }^{6}$

\section{Discussion}

\subsection{The Application Of The Principles Of Insurance Law In Fire Insurance Agreements On Credit Guarantees Attached Object Security Right}

Fire insurance conditions in Indonesia based on the Indonesian Standard Fire Policy. The terms of the policy consists of 22 chapters. To understand the fire insurance contract need to understand the articles of agreement of the standard policy. Fire insurance is a type of coverage provides insurance against the risks caused by the presence of a fire incident on goods insured.

Items which can be insured in the fire insurance is housing, offices, buildings, hospitals, hotels, shopping malls exhibition halls, following factory engine, installation, inventory production, warehouse and others. ${ }^{7}$

The insurance agreement validity of the agreement based on the terms as set out in Article 1320 of the Civil Code, namely: 1 . Agreed to those who bind themselves, 2. Ability to create an engagement; 3. A certain thing; 4. A lawful cause.

Encumbrance an additional agreement attached to the Financing Agreement between the creditor and the Debtor. Encumbrance has the meaning set the Mortgage Act No. 4 of 1996 and the draft Civil Code, as follows: Article 1 (1) of the Act Encumbrance: "Mortgage on land and objects relating to soil, hereinafter called Mortgage, is a security interest is charged on land rights as stipulated in Act No. 5 of 1960 on Basic Regulation of Agrarian, following or not following other objects that are installed on the ground for a particular debt settlement which provides a preferred position to a certain creditor, against another creditor. "

According to Article 1162 of the Civil Code: "Mortgage is a material rights on

\footnotetext{
${ }^{5}$ Explanation of Article 1 paragraph (1) of Law No. 21992 State Gazette of 1992 No. 13 regarding Business Peransuransian

${ }^{6}$ Bambang Sunggono. 2012. Metode Penelitian Hukum. PT. Raja Grafindo Persada. Jakarta. p 43.

7 Darmawi. Herman. 2000. Manajemen Asuransi Dengan Pendekatan Pembahasan Manajemen Perusahaan. Bumi Aksara. Jakarta. p. 107
} 
immovable objects to take the replacement thereof for the repayment of an engagement."

Mortgage as a symbiotic mutualism that serves to guarantee and protect both parties, especially creditors. it is in line with the description in the Mortgage Act 4 of 1996 on Mortgage of Land along with objects related to the land is a "security interest charged on land rights as stipulated in Act No. 5 of 1960 of the Basic Regulation of Agrarian, following or not following other objects that are installed on the ground, for the repayment of certain debt, which gives precedence to the position of certain creditors to other creditors. "

As for collateral that can be used as Encumbrance among others Properties, leasehold, and Broking, as well as the right to use. With the right mortgage, the lender has the right protected by law Mortgage, which objects that serve as collateral and was registered with the Mortgage provides security rights holder's right to precedence (Preferent) from another creditor to look at the ratings Encumbrance.

Lending by banks are the largest element of the assets of the bank, which is also a major asset and simultaneously determining the reciprocation of the bank concerned to exercise their functions and their business of collecting and distributing public funds. ${ }^{8}$ Credit has the elements contained in the credit meaning, namely:

- Trust, namely the belief of the bank for the achievements it provides to borrowers of funds that will be redemption in accordance with the agreement at any given time;

- Time, namely the existence of a certain time period between the granting and repayment of credit, the previous time period prior disetuui or agreed upon between banks and borrowers of funds;

- Achievement and contra, namely the existence of a specific object in the form of achievement and contra at the time of conclusion of the agreement or an agreement granting of credit as outlined in the loan agreements between banks and borrowers of funds, namely in the form of cash or measured with money and interest or yield, or even without reward for islamic banks; risk, ie the risk that might occur during the period between the granting and repayment of the loan, so as to safeguard the provision of credit and cover possible defaults of borrowers of funds, they held binding guarantees (collateral).

So the application of the principles of insurance law in fire insurance agreements on credit guarantees attached object security rights are concerned principle consensual taken from one of the terms of agreement, namely the agreement of both parties. People can not be forced to give agreement. Agreed given by force is a contradiction interminis. Coercion indicates the absence of agreement that may be performed by other parties. The deal gives the option to the parties, to agree or disagree bound by a treaty with legal consequences.

Article 1320 paragraph (1) specifies that, agreement or contract invalid if it is made in the absence of an agreement (consensus) of the party making it. In addition to duress, flawed deal can be made in error, and error.

\subsection{The Weaknesses In The Application Of The Principles Of Insurance Law In Fire Insurance Agreements On Credit Guarantees Attached Object Security Right}

The dynamics of the development of society is inseparable from human nature as

\footnotetext{
8 Djoni S. Gazali \& Rachmadi Usman. 2012. Hukum Perbankan. Sinar Grafika. Jakarta. Second Edition. 2012. p. 269.
} 
beings who need each other or what is known as a social being (zoon politicon). Through social interaction has always done that appear agreement. According to Indonesian dictionary, the agreement is "a written or oral agreement made by two or more parties, each agreement will comply with what is mentioned in the agreement. ${ }^{9}$

Article 1313 Book of Civil Law (hereinafter referred to as the Civil Code) expressed agreement is an act by which one or more persons bind himself to one or more other people. ${ }^{10}$ Whereas under the provisions of Article 1313 of the Civil Code states that the agreement resulted in someone joins himself to others. In this case of a treaty obligation born or achievement of one or more person (party) to one or more person (party) more entitled to these achievements.

Weaknesses stated Article 1313 of the Civil Code are as follows:

- Only about one-sided. It can be seen from the formulation of "one or more persons joined to one or more persons". The word "bind" it is only coming from one side only, not on both sides should be formulated bind themselves to each other, so there is consensus between the parties.

- The word "act" includes without consensus. Definition of actions including measures also carry out tasks without power, unlawful containing no consensus, should use the word agreement

- Understanding agreement is too broad. Definition of agreement in the article too broad because it covers too breeding continuously, mating arranged appointments in the field of family law. In fact, what is meant is the relationship between the creditor and the debtor in the field of wealth only. Agreement desired by the third book of the Civil Code actually is an agreement that is immaterial, not agreements that are personal.

- Without mentioning the purpose of the put on agreement. Without mentioning the purpose of the put on agreement so that the parties bind themselves it is not clear for what. ${ }^{11}$

So the weakness in the application of the principles of insurance law in fire insurance agreements on credit guarantees attached object security right is:

- Risk in Insurance; Fires that occur because of the fire itself, not careful, wrong or evil maids themselves, neighbors, enemies, robbers, and others whatever it's called, or because it causes more fires are unknown, including as a result of a fire that occurred due to fire objects another nearby, such as damage or lack of property and or interest insured by water or other tools used to stifle or extinguish a fire. Similarly, the losses caused by destruction all or part of the insured items on the orders of the authorities to prevent flaring of the fire.

- Exceptions to the items insured. Fire or explosion resulting from a log, decay itself or directly arising from the nature and kind of the goods themselves.

\section{Closing}

\subsection{Conclusion}

- The application of the principles of insurance law in fire insurance agreements on credit guarantees attached object security rights are concerned principle consensual

9 Ministry of National Education. 2005. Indonesia Ihktisar Dictionary Third Edition. Balai Pustaka. Jakarta. p. 458

${ }^{10}$ Ahmadi Miru \& Sakka Pati. 2011. Hukum Perikatan (Penjelasan Makna Pasal 1233 Sampai 1456 KUH Perdata). Rajawali Pers. Jakarta. p. 63.

${ }^{11}$ Abdul Kadir Muhammad. 1992. Hukum Perikatan. Citra Aditya. Bandung. p.78. 
taken from one of the terms of agreement, namely the agreement of both parties. People can not be forced to give agreement. Agreed given by force is a contradiction interminis. Coercion indicates the absence of agreement that may be performed by other parties. The deal gives the option to the parties, to agree or disagree bound by a treaty with legal consequences.

- Weaknesses in the application of the principles of insurance law in fire insurance agreements on credit guarantees attached object encumbrance is Risk Coverage and Exclusions goods insured.

\subsection{Suggestion}

- Insurers and insured full awareness of the rights and obligations of each in running the insurance agreement, especially the attitude of honesty among the parties to avoid any dispute or matter in any form while running an insurance bond between the insurer by the insured.

- In every treaty fire insurance agreed in advance together for the appointment of a direct and unequivocal about the parties which will be used later as an interpreter (independent appraisal), which is expected in the event of a dispute in the future will no longer give rise to multiple interpretations in ratings an object that is covered.

\section{Bibliography}

[1] Abdul Kadir Muhammad. 1992. Hukum Perikatan. Citra Aditya. Bandung

[2] Ahmadi Miru \& Sakka Pati. 2011. Hukum Perikatan (Penjelasan Makna Pasal 1233 Sampai 1456 KUH Perdata). Rajawali Pers. Jakarta

[3] Bambang Sunggono. 2012. Metode Penelitian Hukum. PT. Raja Grafindo Persada. Jakarta

[4] Darmawi Herman. 2000. Manajemen Asuransi dengan pendekatan pembahasan manajemen perusahaan. Bumi Aksara. Jakarta

[5] Departemen Pendidikan Nasional. 2005. Kamus Besar Ihktisar Indonesia Edisi Ketiga. Balai Pustaka. Jakarta

[6] Djoni S. Gazali \& Rachmadi Usman. Hukum Perbankan. Sinar Grafika. Jakarta. Cetakan Kedua. 2012

[7] Junaidi Ganie. Hukum Asuransi Indonesia. Sinar Grafika. Jakarta. 2013

[8] Explanation of Article 1 paragraph (1) of Act No. 21992 State Gazette of 1992 No. 13 regarding Business Insurance 